\title{
MassPUP Project Monitoring
}

\author{
Follow-up Report: \\ Penikese Island School
}

December, 1992

Bill Berg

University of Lowell Photovoltaic Program

Submitted to the

Massachusetts Executive Office of Energy Resources, the

U.S. Department of Energy, and the

Massachusetts Photovoltaic Center

December 21, 1992

Under Cooperative Agreement No. DE-FC04-87AL42558

University of Lowell Research Foundation

450 Aiken Street

Lowell MA 01854 


\section{MassPUP Project Monitoring}

\section{Folllow-up Report: Penikese Island School \\ December, 1992}

\section{Results of Previous Report}

Jim Akens, the engineer in charge of maintaining the system at Penikese Island School, had bypassed all circuit breakers in the charge control unit and had hard wired the charge control unit to the refrigerator, all to reduce the voltage drops in the line. The voltage drops had been preventing the refrigerator from starting properly.

\section{Bypassing of Charge Controller}

Mr. Akens reported that even after the modifications, the batteries still required constant nursing. He felt that they did not store enough charge to keep the refrigerator operating well and he felt that the array was not large enough to keep the batteries fully charged.

The array consists of nine 35 watt Solec modules in parallel. The battery bank consisted of three mini-Absolytes. The load is a Sunfrost 16 cubic foot dual compressor refrigerator-freezer. Additionally, there is a two-way radio for communication with the mainland.

Whenever the batteries were low, the sound quality of the radio changed noticeably, reported Mr. Akens. He said this was the low battery indicator which was as good as the voltmeter on the charge controller.

Since he believed that the batteries were never being fully charged, and since he believed that there were voltage drops and power losses in the charge controller and in the Natural Power watt-hour meter shunt in the charge control unit, Mr. Akens completely bypassed the charge control unit, connecting the array to the refrigerator and to a fuse connected to the battery.

He believed that even with this arrangement, the array was not keeping the battery fully charged.

\section{Battery Replacement}

The Absolyte batteries failed in February, 1992. Mr. Akens replaced them with two 200 amp-hour gel cell batteries, nearly doubling the storage capacity from 223 amp-hours to 400 amp-hours. 
Since replacing the batteries, the refrigerator has operated without a problem until the unusually dark December. One of the immediately noticeable effects of replacing the batteries is that the freezer was able to refreeze partially thawed food. Th food restocking procedure involves purchase of frozen food at 9am, loading on the boat for delivery to the island and placing in the freezer at $3 \mathrm{pm}$. Before the batteries were replaced. the partially thawed food was never fully refrozen.

\section{Suggested limits of the original design}

The system design was reviewed. The contractor assumed a duty cycle of four hours per day for the refrigerator and freezer compressors. Th e compressors draw five amps each, yielding a daily requirement of 40 amp-hours of charge or 480 watt-hours of energy. Twenty watt-hours per day or 1.7 amp-hours was added for the two-way radio. Using the technique and default values presented in the Photovoltaic System Design Practices Manual, the system should provide adequate power and three to four days of storage for the design load.

However, a conversation with Becky Chambers at Sunfrost revealed that the system is seriously underdesigned. The assumed load is far too low. The sixteen cubic foot refrigerator-freezer consumes 45 amp-hours per day when the ambient temperature is $70^{\circ} \mathrm{F}$ and the refrigerator maintains temperature and has no additional load. Consumption increases to 65 amp-hours per day when the ambient temperature is $90^{\circ} \mathrm{F}$.

The no-load values are higher than the design load for the system. Mr. Akens' belief that the system is inadequate for the load is a true belief.

Adding $20 \%$ to the energy usage to account for refrigerator usage and redesigning the system based on the new design load revealed the following:

December is the worst month, even considering a $90^{\circ} \mathrm{F}$ ambient temperature in August.

Using the UMass Lowell loss-of-load-probability-based (LOLP) design method, 1135 Watt modules and 5 Absolyte 12-5000 batteries ( 378 ah), giving 5.6 days of storage, are required for an LOLP of 0.005 . Loosely translated, this LOLP means there will be about one day of energy shortfall in every 200 days.

Using the Photovoltaic System Design Practices Manual, 12 modules are required, and 5 Absolyte batteries ( $383 \mathrm{a}-\mathrm{h})$ for five days of storage.

Mr. Akens took a step in the right direction by installing 400 amp hours of gel cell batteries. 


\section{Next Steps}

Mr. Akens will measure the energy consumption of the refrigerator freezer during January using the watt hour meter installed in the charge controller. It is understood that once the system is properly sized, and the freezer is operating properly, the staff will use the freezer to make ice for soft drinks. Thus, measurements will ba made while the refrigerator is making a few trays of ice a week.

It is also understood that the refrigerator will not start unless the voltage at the compressor is at least 11 volts. Starting current is approximately double the operating current of 5 amps per compressor. The resulting voltage drop requires that the battery operate at somewhat over 11 volts in order to start the compressors. This battery state of charge required to produce 11 volts at the compressor is probably well above the design discharge level of $80 \%$ discharge. In other words, the refrigerator will fail to start well before the battery reaches a state of charge deleterious to the battery, and the design storage of 5 days to an $80 \%$ depth of discharge is closer to three days storage to $50 \%$ depth of discharge. 


\title{
GRAIN DRIER PROJECT
}

\author{
REPORT \\ JULY, 1990 \\ EDITED 1991,1992 \\ SUBMITTED BY
}

\begin{abstract}
University of Lowell Photovoltaic Program:
Stuart Frye, Raymond Hall, Myoung Lee, Chieh Ouyang, B.S.N. Prasad, Juanita Riccobono, Rebecca Rowe, and Sarah Williams (Dagher),

Principal Investigators: William Berg, and José Martín.
\end{abstract}

In partial fulfillment of the requirements of the cooperative agreement No. DE-FC04-87AL42558.

is: 


\section{DISCLAIMER}

This report was prepared as an account of work sponsored by an agency of the United States Government. Neither the United States Government nor any agency thereof, nor any of their employees, makes any warranty, express or implied, or assumes any legal liability or responsibility for the accuracy, completeness, or usefulness of any information, apparatus, product, or process disclosed, or represents that its use would not infringe privately owned rights. Reference herein to any specific commercial product, process, or service by trade name, trademark, manufacturer, or otherwise does not necessarily constitute or imply its endorsement, recommendation; or favoring by the United States Governmeat or any agency thereof. The views and opinions of authors expressed herein do not necessarily state or reflect those of the United States Government or any agency thereof. 